\title{
A Review of Recent Status on Stingrays (Chondrichthyes: Dasyatidae) In Indonesian Waters
}

\author{
Yuanita Windusari ${ }^{1}$ and Muhammad Iqbal ${ }^{2 *}$ \\ ${ }^{1}$ Sriwijaya University, Department of Biology, Indonesia \\ ${ }^{2}$ Sriwijaya University, Faculty of Science, Indonesia
}

Submission: December 17, 2017; Published: March 09, 2018

*Corresponding author: Muhammad Iqbal, Sriwijaya University, Faculty of Science, Conservation Biology Program, Jalan Padang Selasa 524,

Palembang, South Sumatra 30129, Indonesia Email: kpbsos26@yahoo.com

\begin{abstract}
In this paper, the status of stingrays (family Dasyatidae) in Indonesian waters are summarized. There are 40 valid species of stingrays recorded here. Based on distribution of stingrays within seven faunal region of Indonesia, Kalimantan of Indonesian Borneo has 29 species, the largest diversity among other islands; following Sumatra (27 sepecies), Java (25 species), Sulawesi (14 species), Lesser Sundas (16), Mollucas (9 species) and Papua (17 species). According to the recent of Red List of Threatened Species of the International Union for the Conservation of Nature's (IUCN 2017), there are 18 species are listed as threatened species (under Endangered and Vulnerable status), 2 as Near Threatened (NT), 3 as Data Deficient (DD), $5 \mathrm{~s}$ as Least Concern (LC) and 12 species are Not Evaluated (NE). Five species listed as Endangered should have high prioritize for conservation: Fluvitrygon oxyrhynchus (Sauvage, 1878); F. kittipongi (Vidthayanon \& Roberts, 2005); F. signifer (Compagno \& Roberts, 1982); P. solocirostris Last, Manjaji \& Yearsley, 2005; and Urogymnus polylepis (Bleeker, 1852).
\end{abstract}

Keywords: Review; Dasyatidae; Indonesian waters; Diversity; Conservation

\section{Introduction}

The Indonesian archipelago is one of the richest marine biodiversity areas in the world [1]. The country has 4.720 species of fishes, making one the greatest diversity of fish fauna in the world [2]. Many iconic group of fishes known collectively as the 'ray' occur in Southeast Asia, particuarly in Indonesian waters [3-5]. One of 'ray' is stingrays (family Dasyatidae), groups of small to very large myliobatiform fishes (adults from $22 \mathrm{~cm}$ to $260 \mathrm{~cm} \mathrm{DW}$ ) and distinguished by the following combination of characters: body variably depressed with a well-formed oval, circular or rhombic disc that fully incorporates head; snout angular to obtuse and sometimes very elongate; nasal curtain well developed, skirt-shaped, rectangular or bilobed; five gill slits; oral papillae usually present on floor of mouth; tail moderately stout to slender-based and more or less elongated (sometimes very elongate and whip-like); dorsal surface variably covered with dermal denticles, thorns and/or tubercles, smooth to very spiny and often with a median thorn row and/or a median denticle band; no dorsal or caudal fins; 1-4 prominent caudal stings, positioned on tail well posterior to pelvic fins; skin folds variably developed on the ventral and sometimes dorsal midline of tail; dorsal surface plain to strongly patterned, usually darker than ventral surface [6-9]. Recent phylogenetic studies, supported by morphological data, have provided evidence that the Dasyatidae is monophyletic and consists of four major subgroups, the subfamilies Dasyatinae, Neotrygoninae, Urogymninae and Hypolophinae; and a morphologically based review of 89 currently recognised species [6]. In this review, we summary and update current knowledge of the stingrays in Indonesian waters.

\section{Diversity of Stingrays in Indonesian waters}

Table 1 shows 40 valid species of stingrays that occur in Indonesian waters. This checklist is compiled and shortlisted from recent major references [6-8]. The fishes were divided within seven faunal regions of Indonesia, where faunal regions match administrative boundaries and has no political significance [10]. Conservation status covering global threatened species follows recent International Union for Conservation of Nature (IUCN) Redlist 2017 [11].

Two species have been added recently for Sumatran waters [12,13], Fluvitrygon oxyrhynchus and Urogymnus polylepis (Figure $1 \& 2$ ). Based on distribution of stingrays within seven 
faunal region of Indonesia, Kalimantan of Indonesian Borneo has 29 species, the largest diversity among other islands; following Sumatra (27 sepecies) and Java (25 species). There are only

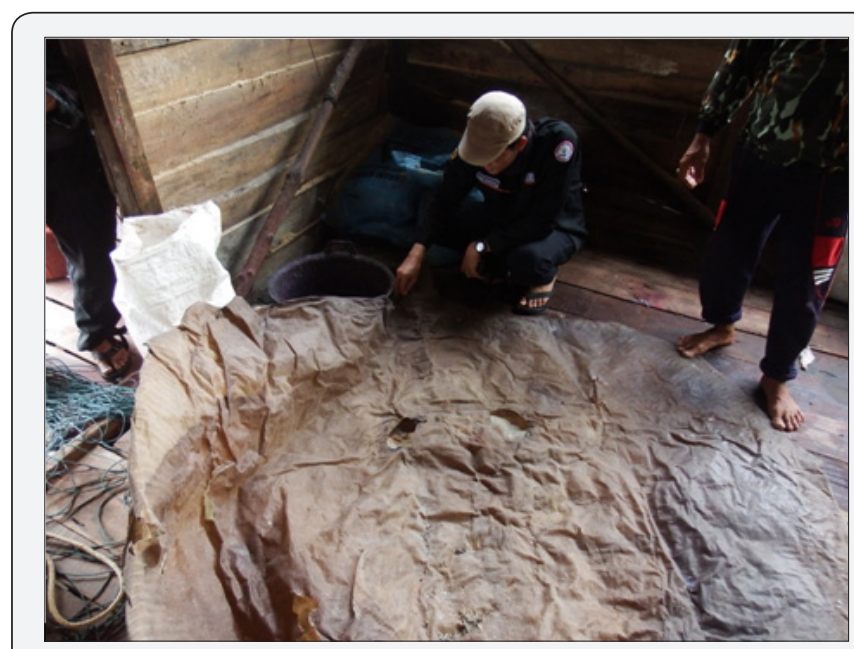

Figure 1: A skin showing dorsal surface of Endangered Urogymnus polylepis (Bleeker, 1852) on 2 April 2016 in Bungin river, Banyuasin district, South Sumatra (photograph by Muhammad lqbal).

\section{Conservation of Stingrays in Indonesian waters}

The status of most of the world's rays have been assesed using a standard international system to characterise the risk of extinction of species: the International Union for the Conservation of Nature's (IUCN) Red List of Threatened Species [14]. Following recent IUCN (2017), there are 18 species are listed as threatened species (under Endangered and Vulnerable status), 2 species listed as Near Threatened, 3 species listed as Data Deficient, 5 species listed as Least Concern and 12 species as Not Evaluated (Table 1). Five species having high prioritize for conservation because listed as Endangered: Fluvitrygon

Table 1: List of stingrays in Indonesian waters. nine species of stingrays found in Mollucas, indicate the lowest number compare to other islands in Indonesian waters.

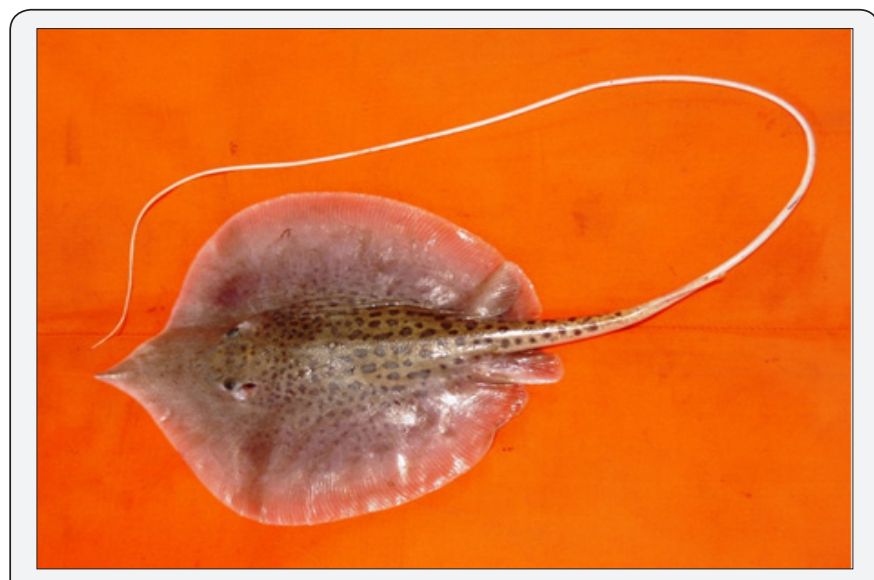

Figure 2 : Fluvitrygon oxyrhynchus (Sauvage, 1878) caught by local fisherman on 24 August 2006 in Musi drainage, South Sumatra province. This is one of very rare stingray in Indonesia (photograph by Muhammad lqbal).

oxyrhynchus; F. kittipongi (Vidthayanon \& Roberts, 2005); F. signifer (Compagno \& Roberts, 1982); P. solocirostris Last, Manjaji \& Yearsley, 2005; and Urogymnus polylepis. Four of these species are inhabit freshwaters. To secure the status of stingrays locally and globally, in addition to the adressing the issue of data deficiency, accurate species identification is needed, the strict enforcement of fishing and protection of measures, a significant increase in scientific observer coverage to monitor catches, and increase research on gear modifications, fishing methods, and habitat identification aimed at itigating bycatch and discard mortality of rays [14].

\begin{tabular}{|c|c|c|c|c|c|c|c|c|c|}
\hline \multirow[b]{2}{*}{ No. } & \multirow[b]{2}{*}{ Species } & \multirow{2}{*}{ IUCN Status } & \multicolumn{7}{|c|}{ Distribution } \\
\hline & & & $\mathbf{S}$ & $\mathbf{K}$ & $\mathbf{J}$ & $\mathbf{S}$ & $\mathbf{M}$ & $\mathbf{L}$ & $\mathbf{P}$ \\
\hline 1 & Bathytoshia lata (Garman, 1880) & LC & & & + & & & + & \\
\hline 2 & B. heterura (Bleeker, 1852) & NE & + & + & + & & & & \\
\hline 3 & B. javaensis (Last \& White, 2013) & $\mathrm{NE}$ & & & + & & & & \\
\hline 4 & Fluvitrygon oxyrhynchus (Sauvage, 1878) & EN & + & + & & & & & \\
\hline 5 & F. kittipongi (Vidthayanon \& Roberts, 2005) & EN & & + & & & & & \\
\hline 6 & F. signifer (Compagno \& Roberts, 1982) & EN & + & + & & & & & \\
\hline 7 & $\begin{array}{l}\text { Hemitrygon bennettii (Müller \& Henle, } \\
1841 \text { ) }\end{array}$ & DD & + & + & & & & & \\
\hline 8 & H. longicauda (Last \& White, 2013) & NE & & & & & & & + \\
\hline 9 & H. parvonigra (Last \& White, 2008) & DD & & & + & & & + & \\
\hline 10 & Himantura uarnak (Gmelin, 1789) & $\mathrm{VU}$ & + & + & + & + & + & + & \\
\hline 11 & H. australis Last, White \& Naylorr, 2016 & $\mathrm{NE}$ & & & & & & & + \\
\hline 12 & $\begin{array}{l}\text { H. leoparda Manjaji-Matsumoto \& Last, } \\
2008\end{array}$ & VU & + & + & + & + & + & + & + \\
\hline
\end{tabular}


Oceanography \& Fisheries Open access Journal

\begin{tabular}{|c|c|c|c|c|c|c|c|c|c|}
\hline 13 & H. undulata (Bleeker, 1852) & $\mathrm{VU}$ & + & + & + & + & & & \\
\hline 14 & Maculabatis gerrardi (Gray, 1851) & $\mathrm{VU}$ & + & + & + & & & & \\
\hline 15 & $\begin{array}{l}\text { M. astra (Last, Manjaji-Matsumoto \& } \\
\text { Pogonoski, 2008) }\end{array}$ & LC & + & + & + & + & & + & \\
\hline 16 & M. marucra (Bleeker, 1852) & $\mathrm{NE}$ & & & & & & & + \\
\hline 17 & M. pastinacoides (Bleeker, 1852) & $\mathrm{VU}$ & + & + & + & & & & \\
\hline 18 & Megatrygon microps (Annandale, 1908) & DD & + & + & & + & & + & + \\
\hline 19 & Neotrygon annotata (Last, 1987) & NT & & & + & & & + & + \\
\hline 20 & N. australiae (Last, White \& Seret, 2016) & $\mathrm{NE}$ & & & & & & + & + \\
\hline 21 & $\begin{array}{l}\text { N. caeruleopunctata (Last, White \& Seret, } \\
\text { 2016) }\end{array}$ & $\mathrm{NE}$ & + & & + & & & & \\
\hline 22 & N. onectatus (Last, White \& Seret, 2016) & $\mathrm{NE}$ & + & + & + & + & & & \\
\hline 23 & N. picta Last \& White, 2008 & LC & & & & & & & + \\
\hline 24 & N. varidens (Garman, 1855) & $\mathrm{NE}$ & & + & & & & & \\
\hline 25 & Pastinachus ater (Macleay, 1883) & LC & + & + & + & + & + & + & + \\
\hline 26 & $\begin{array}{l}\text { P. gracilicaudus Last \& Manjaji-Matsumoto, } \\
\qquad 2010\end{array}$ & $\mathrm{NE}$ & + & + & + & & & & \\
\hline 27 & P. solocirostris Last, Manjaji \& Yearsley, 2005 & EN & + & + & + & & & & \\
\hline 28 & P. stellurostris Last, Fahmi \& Naylor, 2010 & $\mathrm{NE}$ & & + & & & & & \\
\hline 29 & Pateobatis fai (Jordan \& Seale, 1906) & $\mathrm{VU}$ & + & + & + & & & + & + \\
\hline 30 & $\begin{array}{l}\text { P. hortlei (Last, Manjaji-Matsumoto \& } \\
\text { Kailola, 2006) }\end{array}$ & $\mathrm{VU}$ & & & & & & & + \\
\hline 31 & P. jenkinsii (Annandale, 1909) & $\mathrm{VU}$ & + & + & + & + & + & + & + \\
\hline 32 & P. uarnacoides (Bleeker, 1852) & $\mathrm{VU}$ & + & + & + & + & & & \\
\hline 33 & Pteroplatytrygon violacea (Bonaparte, 1832) & LC & + & + & + & + & + & + & + \\
\hline 34 & Taeniura lymma (Forsskål, 1775) & NT & + & + & + & + & + & + & + \\
\hline 35 & Taeniurops meyeni (Müller \& Henle, 1841) & $\mathrm{VU}$ & + & + & + & + & + & + & + \\
\hline 36 & Telatrygon biasa Last, White \& Naylorr, 2016 & $\mathrm{NE}$ & + & + & + & + & & & \\
\hline 37 & Urogymnus polylepis (Bleeker, 1852) & EN & + & + & & & & & \\
\hline 38 & U. asperrimus (Bloch \& Schneider, 1801) & $\mathrm{VU}$ & + & + & + & + & + & + & + \\
\hline 39 & U. granulatus (Macleay, 1883) & $\mathrm{VU}$ & + & + & + & & + & + & + \\
\hline 40 & $\begin{array}{l}\text { U. lobistoma (Manjaji-Matsumoto \& Last, } \\
\text { 2006) }\end{array}$ & $\mathrm{VU}$ & + & + & & & & & \\
\hline Total & & & 27 & 29 & 25 & 14 & 9 & 16 & 17 \\
\hline
\end{tabular}

Note:

I. IUCN global status, $C R=$ Critically Endangered, EN = Endangered, VU = Vulnerable,$N T=$ Near Threatened, DD = Data Deficient, LC $=$ Least Concern, NE $=$ Not Evaluated .

II. Distribution abbreviations, $\mathrm{S}=$ Sumatara, $\mathrm{K}=$ Kalimantan (Indonesian Borneo), $\mathrm{J}=$ Java, $\mathrm{S}=$ Sulawesi, $\mathrm{M}=\mathrm{Mollucas}, \mathrm{L}=\mathrm{Lesser}$ Sunda, $\mathrm{P}=$ Papua (West Papua, Indonesian Papua).

\section{Conclusion}

Recent status of stingrays (family Dasyatidae) in Indonesian waters are summarized here. This general review may give obvious diversity and conservation challenges. We supose that further research and monitoring are needed to clarify local status and distribution of stingrays in Indonesian waters, particularly in area where rarely explored.

\section{Acknowledgment}

Few visits to Musi basin have drawn attention to stingrays status in Sumatra. Thanks to Project Aware Foundtion who granted MI to conduting aquatic survey in South Sumatran waters. We are very grateful to all researchers, students and volunteers who facilitated us during various fieldworks in South Sumatran waters during 2006-2016. 


\section{References}

1. Tomascik T, Mah AJ, Nontji A, Moosa ML (1997) The ecology of Indonesian sean, Part II. Periplus Editions, Singapore.

2. Froese R, Pauly D (2017) FishBase, World Wide Web electronic publication.

3. Compagno LJV, Roberts TR (1982) Freshwater stingrays (Dasyatidae) of Southeast Asia and New Guinea, with description of a new species of Himantura and reports of unidentified species. Environmental Biology of Fishes 7(4): 321-339.

4. Last PR, de Carvalho MR, Naylor GJP, Seret B, Stehmann MFW, et al (2016) Introduction. In: Last others (Eds.). Rays of the world, Cornell University Press, Ithaca, USA, pp. 1-9.

5. Kottelat M (2013) The fishes of inland waters of Southeast Asia: a catalogue and core bibliography of the fishes known to occur in freshwaters, mangroves and estuaries. Raffles Bulletin of Zoology Supplement 27: 1-663.

6. Last PR, Naylor GJP, Manjaji-Matsumoto BM (2016) A revised classification of the family Dasyatidae (Chondrichthyes: Myliobatiformes) based on new morphological and molecular insights. Zootaxa 4139(3): 345-368.

7. Last PR, Compagno LJV (1999) Dasyatidae. In: Carpernter KE, Niem VH (Eds.). FAO species identification guide for fishery purposes. The living marine resources of the Western Central Pacific. Volume 3. Batoid fishes, chimaeras and bony fishes part 1 (Elopidae to Linophrynidae), Food and Agriculture Organization of the United Nations, Rome, Italy, pp. $1479-1510$

8. Last PR, Manjaji-Matsumoto BM, Naylor GJP, White WT (2016) Stingrays, Family Dasyatidae. In: Last others (Eds.). Rays of the world, Cornell University Press, Ithaca, USA, pp. 522-618.

9. Nelson JS, Terry C, Grande TC, Wilson MVH (2016) Fishes of the World. ( $5^{\text {th }}$ edn), John Wiley \& Sons, Hoboken, USA.

10. Andrew P (1992) The birds of Indonesia, a checklist (Peter's sequence), Kukila Checlist no. 1, Indonesian Ornithological Society, Jakarta, Indonesia.

11. IUCN (2017) The IUCN Red List of Threatened Species.

12. Iqbal M, Yustian I (2016) Occurrence of the giant freshwater stingray Urogymnus polylepis in Sumatra, Indonesia (Chondrichthyes: Dasyatidae). Ichthyological Exploration of Freshwaters 27(4): 333336.

13. Iqbal M, Setiawan D, Ajiman (2017) Presence of Fluvitrygon oxyrhynchus in Sumatra, Indonesia (Chondrichthyes: Dasyatidae) Ichthyological Exploration of Freshwaters 28(1): 85-87.

14. Kyne PM (2016) Ray Conservation. In: Last others (Eds.). Rays of the world, Cornell University Press, Ithaca, USA, pp. 21-24.

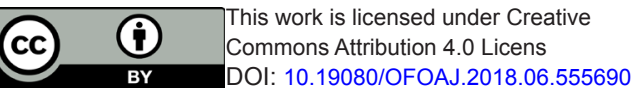

Your next submission with Juniper Publishers will reach you the below assets

- Quality Editorial service

- Swift Peer Review

- Reprints availability

- E-prints Service

- Manuscript Podcast for convenient understanding

- Global attainment for your research

- Manuscript accessibility in different formats ( Pdf, E-pub, Full Text, Audio)

- Unceasing customer service

Track the below URL for one-step submission https://juniperpublishers.com/online-submission.php 